\title{
Lytte, lete, tenke
}

Som klinisk lærer på medisinstudiet starter jeg gjerne et nytt semester med å spørre studentene: Hva skal en allmennlege gjøre for å finne ut om en pasient har kreft? Det vanligste svaret jeg får, er at det må tas tester: blodprøve, biopsi, røntgenundersøkelse, skopiundersøkelse, MR eller PET-skan. Det er tankevekkende for oss lærere at knapt noen sier det selvsagte: at legen først må spørre om pasientens plager og bekymringer og stille nøkkelspørsmål der svarene kan underbygge en mistanke om kreft, slik som vekttap, slapphet, langvarig hoste, avføringsendringer, sår som ikke vil gro.

Anamnesens betydning for medisinsk diagnostikk kan neppe overvurderes. Likevel er det et faktum at mange diagnoser overses eller forsinkes fordi legene ikke har fanget opp viktige anamnestiske opplysninger (1). Troen på nye og avanserte metoder innen medisinsk teknologi kan føre til at evnen til å vurdere betydningen av enkle opplysninger og kliniske observasjoner svekkes.

På den annen side er anamnesen sjelden tilstrekkelig til å stille en diagnose. Uerfarne studenter kan bekymre seg allerede under anamneseopptaket om de skal makte å stille den riktige diagnosen. Mange av oss har som lege fått erfare hvor pinlig og vanskelig det kan være når man etter et kort anamneseopptak forteller pasienten hva man mener han eller hun lider av, og det senere i samme konsultasjon blir åpenbart at pasienten lider av noe helt annet. Det kan bli vanskelig å ro i land. Man kan gjerne mistenke tidlig i prosessen hvilken sykdom pasienten har, men alle differensialdiagnostiske muligheter må holdes åpne til etter at den somatiske undersøkelsen er gjennomført, ofte lengre. Diagnoser må ikke stilles for tidlig, ved å gjette eller når man er på tynn is. Diagnostikk er ingen gjettekonkurranse.

Anamnesens funksjon er i utgangspunktet først og fremst å få frem opplysninger om symptomer og andre forhold som kan danne deler av grunnlaget for diagnosen. Men like viktig er det at legen under anamneseopptaket opptrer på en måte som gjør at pasienten får tillit til ham eller henne (2). Legen må også observere pasientens atferd og reaksjoner på ulike spørsmål for å danne seg et inntrykk av pasientens generelle helse, personlighet og forutsetninger for å følge opp behandlingen.

Studier viser at mange leger avbryter pasienten svært tidlig i en konsultasjon (3). På den måten risikerer man at verdifulle opplysninger ikke kommer frem, og at pasienten føler seg avspist og ikke lyttet til. Det er skadelig for lege-pasient-forholdet. Legen bør tilstrebe å la pasienten først fortelle sin historie uten inngripen og lytte med oppmerksomhet og empati. Legen bør ikke se på pasientens syke legemsdel eller på PC-skjermen under anamneseopptaket - se heller pasienten i øynene, slik man gjør ved enhver annen samtale. Først når pasienten synes å ha sagt sitt (eller har kommet på avveie i sin historie), bør legen komme inn med avklarende og målrettede spørsmål. Dette er ikke så tidkrevende som man skulle tro (2).

Etter min mening bør anamneseopptaket være avsluttet før man tar fatt på den somatiske undersøkelsen, for det kan være vanskelig å ta opp sensitive spørsmål etter at pasienten har kledd av seg. Man sparer sjelden tid på å gjøre anamneseopptak og somatisk undersøkelse samtidig, men i kritiske situasjoner kan det selvfølgelig være påkrevet.

Studenter bør lære seg å gjennomføre den somatiske undersøkelsen på en systematisk og strukturert måte, der rekkefølgen av hva som undersøkes, er konsistent og følger etablert konvensjon. Det kan være lurt å notere ned funnene underveis. Her har hver spesialitet sin måte å gjøre det på, men de har alle det til felles at man begynner med overordnede og generelle observasjoner, for deretter å registrere spesifikke funn etter en fast oppsatt mal som sikrer at alle forhold og funn kommer med.

Når diagnosen så skal stilles, kan dette ofte gjøres på grunnlag av mønstergjenkjenning, dvs. et sett av symptomer og funn som studenten kjenner igjen, og som passer med en sykdom. Andre ganger må man ta utgangspunkt i ett eller flere symptomer, opplysninger eller funn for å gjennomføre et resonnement som leder frem til en mulig, antatt eller sikker diagnose. Rekvisisjon av supplerende undersøkelser bør skje målrettet med det formål å styrke eller svekke diagnostiske muligheter. Når prøver er tatt og diagnosen er stilt, kan behandling igangsettes.

Ved starten av et nytt høstsemester og et nytt akademisk år er det grunn til å minne om betydningen av at medisinstudentene trenes i godt anamneseopptak, strukturert somatisk undersøkelse og diagnostisk resonnement. Det er dette, blant annet, som skal til for å bli en dyktig lege: evnen til å lytte, lete og - viktigst av alt - tenke.

\section{Litteratur}

1. Nguyen TV, Hong J, Prose NS. Compassionate care: enhancing physicianpatient communication and education in dermatology: Part I: Patient-centered communication. J Am Acad Dermatol 2013; 68: 353.e1-8.

2. Mauksch LB, Dugdale DC, Dodson S et al. Relationship, communication, and efficiency in the medical encounter: creating a clinical model from a literature review. Arch Intern Med 2008; 168: 1387-95.

3. Levine M. Tell the doctor all your problems, but keep it to less than a minute. The New York Times 1.6.2004. www.nytimes.com/2004/06/01/health/ tell-the-doctor-all-your-problems-but-keep-it-to-less-than-a-minute.html (2.6.2015). 